\title{
DNA Fingerprinting Profile and Quality Control Standardization of Folklore Medicinal Plant Exacum lawii
}

\author{
Sonam Sharma, Siva Hemalatha*
}

\section{Sonam Sharma,}

Siva Hemalatha*

Department of Pharmaceutics, Indian Institute of Technology, Banaras Hindu University, Varanasi-221005, Uttar

Pradesh, INDIA.

\section{Correspondence}

\section{Siva Hemalatha}

Department of Pharmaceutics, Indian Institute of Technology (Banaras Hindu University) Varanasi, (U.P.) 221005, INDIA

Phone no:+919415256481

E-mail: shemalatha.phe@itbhu.ac.in

\section{History}

- Submission Date: 05-06-2017

- Review completed: 28-07-2017;

- Accepted Date: 22-08-2017

DOI : 10.5530/pj.2017.6.122

Article Available online http://www.phcogj.com/v9/i6

\section{Copyright}

(c) 2017 Phcog.Net. This is an openaccess article distributed under the terms of the Creative Commons Attribution 4.0

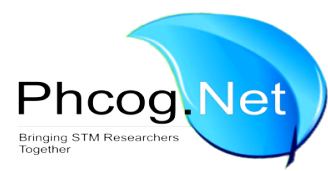

\begin{abstract}
Context and Aim: Exacum lawii (Gentianaceae) is bitter folk medicinal herb. The study deals with molecular investigation by DNA fingerprinting profile of Exacum lawii, quality control and phytochemical standardization of Exacum lawii. Methods: The DNA fingerprinting profile was performed by RAPD technique using 3 pairs of primers. The quality control standardization was done as per the WHO guidelines and official methods of AOAC. Phytochemical standardization employed quantitative estimations of phytoconstituents by spectrophotometric and identification using GCMS technique. The quantification of Swertiamerin and Ursolic acid in Exacum lawii was carried by HPLC. Results: Macroscopical and microscopical examination confirmed the diagnostic morphological and histological features. The content of vitamins, minerals and fatty acids were estimated. Physicochemical parameters obtained within the provided limits as per WHO. The phytochemical screening of ethanolic extract and its fraction revealed the presence of alkaloids, flavonoids, phenols, tannins, terpenoids, glycosides and steroids Total phenolics $(57.4 \mathrm{mg} / \mathrm{g}$ tannic acid equivalent), total tannins $(15.3 \mathrm{mg} / \mathrm{gm})$, total flavonoids (51.4 $\mathrm{mg} / \mathrm{gm}$ rutin equivalent), total flavonols $(5.4 \mathrm{mg} / \mathrm{gm})$ and carbohydrates (12.6 mg/gm D-fructose equivalent) content were estimated using spectroscopic techniques. The GC-MS data revealed 20 compounds. Swertiamerin and Ursolic acid content was 119.59 $\mathrm{mg} / \mathrm{gm}$ and $5.34 \mathrm{mg} / \mathrm{gm}$ respectively. Conclusion: Present study provides the referential information to develop a monograph for quality control standardization of Exacum lawii.

Key words: Exacum lawii, DNA fingerprinting, Swertiamerin, Ursolic acid, GC-MS.
\end{abstract}

\section{INTRODUCTION}

Medicinal plants are popularly used for various diseases due to their acceptability, effectiveness, affordability, safety and low cost. ${ }^{1}$ According to WHO it was estimated that up to $80 \%$ of people still rely primarily on traditional remedies for healthcare. The medicinal value of these plants is due to their elemental composition and the presence of wide range of phytochemicals. ${ }^{2}$ The name Exacum was first used by Linnaeus. The genus Exacum (Gentianaceae, tribe Exaceae) consists of 64 species distributed across palaeotropical regions. Including Africa, Madagascar, Socotra, Himalayas, Arabian Peninsula, India, Sri Lanka, Southern China and Malaysia, and Northern Australia. Exacum lawii C.B. Clarke, species of genus Exacum is small herb commonly distributed in the Western peninsula, Western coast region of India, Mysore and Coimbatore, Southern part India. It is endemic to Jarandeshwar hill from Satara district, Maharashtra and Western ghat of Karnataka. Plant taxonomy of Exacum lawii is shown below. The Exacum lawii is annual, glabrous, small erect herb rarely reaching $15 \mathrm{~cm}$ tall and flowers are bluish-purple. Whole plant has been used traditionally as the folk remedy for the treatment of kidney disorders, eye diseases and also used as laxative. The common name is Law's Persian violet. It is locally known as Lahan chirayata in Maharashtra, Manali in Malayalam, Marukozhunthu in Tamil. The Exacum lawii is annual, glabrous, small erect herb rarely reaching $15 \mathrm{~cm}$ tall. Flowers are bluish-purple. ${ }^{3-14}$

Class: Equisetopsida C. Agardh

Subclass: Magnoliidae Novák ex Takht.

Superorder: Asteranae Takht.

Order: Gentianales Juss. ex Bercht. and J. Presl

Family: Gentianaceae Juss.

Genus: Exacum L.

Even though the plant has traditional medicinal values, still there is no data available on its quality control profile. The DNA fingerprinting profile, pharmacognostical, physicochemical and phytochemical standardization of herb provides guideline for correct identification and prevention of adulterants. Therefore the aim of the present study is to develop the scientific standardization monograph for whole plant of Exacum lawii and DNA fingerprinting profile. These are contemplating as the primary steps for quality control standardization of Exacum lawii. 


\section{MATERIAL AND METHOD}

\section{Plant authentication and extraction process}

The plant samples were collected in the month of August-October from Mahabaleshwar, Maharashtra, India. The plant was identified and authenticated by Dr. N. M. Dongarwar, Assistant Professor, Department of Botany, Rashtrasant Tukadoji Maharaj Nagpur University, India. Voucher specimen (Cog/EL/2014-15) was deposited for future reference in Pharmacognosy laboratory of Department of Pharmaceutics, Indian Institute of Technology (Banaras Hindu University), Varanasi, India. The whole plant was freshly collected, thoroughly washed and shade dried for one week at temperature not exceeding $60^{\circ} \mathrm{C}$ to prevent the deactivation of thermolabile phytoconstituents. The dried plant was coarsely powdered using mechanical grinder, passed through 60 mesh sieve size and stored at room temperature until extraction. The coarsely powdered drug was used for powder study and physiochemical parameters. For phytochemical screening, the powdered drug $(500 \mathrm{gm})$ was exhaustively extracted for $24 \mathrm{~h}$ by soxhlation using $95 \%$ ethanol (3 litres) as solvent for extraction (using soxhlet apparatus). The extract was concentrated using vacuum rotary evaporator (IKA Germany) and dried in vacuum desiccator. The obtained extract (ELE) was then fractionated using different solvents such as petroleum ether, toluene, chloroform, ethyl acetate and water. The extract was then evaluated for colour, taste and extractive value.

\section{Random Amplified Polymorphic DNA (RAPD) fingerprinting profile \\ DNA isolation, Quantification and Electrophoresis}

The fresh plants of Exacum lawii were flashed with liquid nitrogen followed by grinding of frozen tissues using a mortar and pestle. $3 \mathrm{mg} / \mathrm{ml}$ proteinase $\mathrm{k}$ was added to the samples in eppendorf. These samples were incubated at $37^{\circ} \mathrm{C}$ for $1 \mathrm{~h}$ in a water bath shaker. Pre-warmed extraction buffer (100 mM Tris- $\mathrm{HCl}$ (pH 8.0), $2.5 \mathrm{M} \mathrm{NaCl}, 20 \mathrm{mM}$ EDTA, $3 \%$ CTAB, $1 \%(\mathrm{v} / \mathrm{v}) 2$-mercaptoethanol and $1 \%$ Sarkosyl) was added after incubation kept in shaker water bath at $65^{\circ} \mathrm{C}$. Supernatant $(5 \mathrm{ml})$ were separated from each tube and allowed to cool at room temperature followed with equal volume chloroform: isoamyl alcohol (24:1) solution. An upper aqueous and a lower organic solvent layer in each tube were formed. Tubes were slowly inverted without shearing of DNA until homogenous emulsion was formed. The tubes were centrifuged at 9200 $\mathrm{rcf}$ for $15 \mathrm{~min}$ at $4^{\circ} \mathrm{C}$ using $3 \mathrm{~K} 30$ laboratory centrifuge. Upper transparent aqueous layer containing nucleic acid was transferred to another $50 \mathrm{~mL}$ tube using a $5 \mathrm{~mL}$ micropipette with broad bore tips. The tubes left over night at $-20^{\circ} \mathrm{C}$ for nucleic acid precipitation after adding double volume of pre-chilled ethanol and $3 \mathrm{M}$ sodium acetate $(\mathrm{pH}$ 5.2). The tubes were centrifuged at 20,000 $\mathrm{rcf}$ for $15 \mathrm{~min}$ to pellet the precipitated nucleic acid. The supernatant were removed and pellets obtained were washed in $70 \%$ ethanol. The pellets were dried in hot air blower for complete removal of ethanol. These pellets were suspended in $50 \mu \mathrm{l}$ of TE buffer (Tris- $\mathrm{HCl} 10 \mathrm{mM} \mathrm{pH} 8.0$ and EDTA $1 \mathrm{mM}$ ). The suspension was incubated with pancreatic RNaseA (final concentration $0.2 \mu \mathrm{g} / \mu \mathrm{l}$ ) for $2 \mathrm{~h}$ at $37^{\circ} \mathrm{C}$ to remove RNA. The resulting suspensions contained DNA from Exacum lawii plant.

The concentration of DNA was checked by measuring $\mathrm{A}_{260} / \mathrm{A}_{280}$ ratio in a Hitachi UV-Vis spectrophotometer. Isolated DNA was electrophoresed in $0.8 \%$ agarose gel containing $1 \mu \mathrm{g} / \mathrm{ml}$ ethidium bromide using TAE electrophoresis buffer ( $40 \mathrm{mM}$ Tris-acetate and $1 \mathrm{mM}$ EDTA of $\mathrm{pH}$ 8.0) and photographed in the gel documentation system (Bio-Rad, USA).

\section{RAPD-PCR and Electrophoresis}

Six different primers were selected to generate reproducible amplification products. ${ }^{15,16}$ Sequences of the primers (Sigma grade) used for RAPD-
PCR are given in Table 1. PCR was performed in $25 \mu$ reaction mixture containing $40 \mathrm{ng}$ DNA, $2.5 \mu \mathrm{l}$ of 10X PCR buffer $(500 \mu \mathrm{M}$ dNTPs, $4.5 \mathrm{mM}$ $\mathrm{MgCl}_{2}, 0.5 \mu \mathrm{M}$ of each primer and 0.6 unit per $\mu \mathrm{l}$ Taq DNA polymerase (Bangalore Genei, India) in an Icycler PCR thermal cycler (Bio-Rad, USA). The thermal cycler profile was as follows: initial denaturation for $1 \mathrm{~min}$ at $95^{\circ} \mathrm{C}$ followed by 35 incubation cycles each consisting of $94^{\circ} \mathrm{C}$ for $30 \mathrm{sec}$ denaturation, $30 \mathrm{sec}$ annealing at $48^{\circ} \mathrm{C}$ then $60 \mathrm{sec}$ at $68^{\circ} \mathrm{C}$ and a final 5 min elongation at $68^{\circ} \mathrm{C}$. Primers were combined in an equimolar ratio for the multiplex reaction. PCR products were seperated by electrophoresis in $1.5 \%(\mathrm{w} / \mathrm{v})$ agarose gel using TAE buffer (40 mM Tris-acetate and $1 \mathrm{mM}$ EDTA at $\mathrm{pH} 8.0$ ) containing $0.5 \mu \mathrm{g} / \mathrm{ml}$ ethidium bromide and photographed. RAPD banding profiles were scored by using an Amersham 100-bp ladder on the basis of presence or absence of the bands of a particular size were determined utilising fingerprinting II version-3 software (Bio-Rad, USA).

\section{Pharmacognostical studies}

\section{Morphological, microscopical and powder evaluation}

Morphological, histological and powder evaluation were done according to standard procedure given in Trease and Evans. ${ }^{17,18}$ For morphological evaluation, the whole plant was evaluated for the size, texture, colour, shape, odour and taste. For microscopical study whole plant was preserved in n-butyl alcohol of different proportion.

The sections were taken with the help of rotary microtome (York Scientific Industries Pvt. Ltd.) and sections were dehydrated with different ratio of absolute alcohol and then stained with safranin. Finally the obtained stained sections were permanently mounted with DPX for histological study. ${ }^{19}$

Sections were also analysed in SEM (scanning electron microscope quanta 200) at low vacuum. The pressure was maintained in the range of 5.99 to $6.02 \mathrm{e}^{-1}$ torr. The detector used was secondary electron detector. The sections were placed on a circular aluminium specimen stub, pre-coated with silver glue (for increasing conductivity of electrons) and placed over observation area. It was then observed under the SEM in varying magnifications and micrographs were recorded.

Powdered drug was stained with phloroglucinol and $\mathrm{HCl}$ and observed under microscope. For the study of macerated tissue and isolated cells plant was treated with the concentrated nitric acid and powdered potassium chlorate. After washing with distilled water, tissues were finally mounted in glycerine for observation. Photographs of different magnifications were taken with Nikon Trinocular Microscopic unit, Model E-200, Japan. Quantitative microscopy was done by using anatomical section and epidermal layer of fresh leaves. ${ }^{20,21}$

\section{Nutritional content analysis and physicochemical Evaluation}

Nutrient contents analysis is the amount of vitamins, minerals, calories obtained from fat, fatty acid profile and its composition was determined using Association of Official Analytical Chemists Methods. The powdered plant material was utilised for further physicochemical parameters like extractive value, moisture content, swelling index, water soluble ash, total ash, acid insoluble ash, foaming index, bulk density, $\mathrm{pH}$, volatile oil content (by distillation method), foreign matter, crude fibre content and volatile oil determination as per WHO 2002 guidelines. ${ }^{22,23}$ Each study was performed in triplicate; mean values with standard error of mean (SEM) were calculated.

\section{Pesticide residue and heavy metal estimation}

The quantification of pesticide residue was estimated following the methods described in WHO 2002 guidelines. The present investigation involved estimation of four important heavy metals viz. $\mathrm{Pb}, \mathrm{Hg}, \mathrm{Zn}$ and 
Cd. Two $(\mathrm{g})$ of powdered drug was digested with $10 \mathrm{ml}$ concentrated nitric acid followed by heating in a hot plate at $95^{\circ} \mathrm{C}$ for $15 \mathrm{~min}$. This process was repeated twice for another $30 \mathrm{~min}$ until the red fumes of nitric acid disappear. The solution was cooled at room temperature and $2 \mathrm{ml}$ of deionised water and $3 \mathrm{ml}$ hydrogen peroxide $(30 \% \mathrm{v} / \mathrm{v})$ was added to start the peroxide reaction. After the reaction was completed, add $5 \mathrm{ml}$ of concentrated hydrochloric acid followed with $10 \mathrm{ml}$ deionised water and heat the sample for an additional $15 \mathrm{~min}$. The sample was cooled, filtered and make up to $50 \mathrm{ml}$ of volume. The estimation of heavy metals was analysed by using atomic absorption spectroscopy (Shimadzu-AA6300). Data was obtained in parts per million $(\mathrm{ppm}),(1 \mathrm{ppm}=1 \mathrm{mg} / \mathrm{kg}){ }^{24}$

\section{Phytochemical evaluation}

\section{Preliminary Phytochemical screening}

Preliminary phytochemical screening of ELE and its sub-fractions were performed to evaluate the presence of various classes of phytochemicals like alkaloids, glycosides, flavonoids, steroids/triterpenoids, phenolics, tannins, saponins, mucilages, protein, amino acids and carbohydrates as per standard procedure..$^{25-27}$

\section{Quantitative estimation}

The total phenolic content of extract was done by Folin-Ciocalteu (FC) assay as per standard protocol. ${ }^{28}$ The total flavonoid content was expressed in rutin equivalent (RE). The total flavonol content was also determined by Aluminium chloride method. ${ }^{29}$ The total alkaloid content was measured by standard procedure..$^{30}$

\section{HPLC standardization of Swertiamerin and Ursolic acid}

HPLC analysis was carried out by using Waters 1500-series pump (Milford, MA, USA) attached to Waters 2998 photodiode array detector and data were analysed using waters Breeze software (Waters, USA). The mobile phase and sample were filtered through a $0.45 \mu \mathrm{m}$ membrane filter by solvent filtration apparatus (Millipore, USA). Analysis of the samples was carried out in Column Lichro CART ${ }^{\oplus} 250-4$ C18 column and methanol-water (1:1) to get better separation, peak shape and resolution at UV $238 \mathrm{~nm}$ and thus used for further analysis.

The chromatographic conditions for swertiamerin: flow gradient started with flow rate of $0.5 \mathrm{ml} / \mathrm{min}$. At $4.9 \mathrm{~min}$, the flow rate was increased to 0.8 $\mathrm{ml} / \mathrm{min}$ then increased to $1.0 \mathrm{ml} / \mathrm{min}$ at $5.1 \mathrm{~min}$. The flow rate was kept constant up to $5.4 \mathrm{~min}$ and then finally decreased to $0.5 \mathrm{ml} / \mathrm{min}$, restoring the initial conditions at $8 \mathrm{~min}$. Detector's wavelength was $238 \mathrm{~nm}$ and the injection volume was $10 \mu$ l. The best base line separation (peak purity $>95 \%$ ) for swertiamarin was achieved at $238 \mathrm{~nm}$ also reported earlier. Swertiamarin was found to show maximum absorption at $\lambda \max 238 \mathrm{~nm}$ in three-dimensional ultraviolet absorption spectra using photo diode array (PDA) detector. ${ }^{31}$

The chromatographic conditions form ursolic acid: Stock solution was prepared by $1 \mathrm{mg} / \mathrm{ml}$ in methanol and serial dilutions are made for calibration curve. An isocratic mobile phase of acetonitrile: methanol $(80: 20 \mathrm{v} / \mathrm{v})$ with an elution volume of $0.5 \mathrm{ml} / \mathrm{min}$ for identification of ursolic acids. The ursolic acid was detected at maximum absorption of $\lambda \max 210 \mathrm{~nm}^{32}$

\section{Extract composition by GCMS analysis}

GC-MS analysis of the ethanolic extract of Exacum lawii was performed Shimadzu GCMS-QP-2010 plus system. RTx-5 Sil MS column (internal diameter $30 \mathrm{~m} \times 0.25 \mathrm{~mm}, 0.25 \mathrm{~m}$ film thickness) was used for the analysis. Helium was used as the carrier gas. The injector temperature was maintained at $270^{\circ} \mathrm{C}$, Oven temperature programme from $80^{\circ} \mathrm{C}$ to $210^{\circ} \mathrm{C}$ at $4^{\circ} \mathrm{C} / \mathrm{min}$ in the interval time of $2 \mathrm{~min}$ and from $210^{\circ} \mathrm{C}$ to $300^{\circ} \mathrm{C}$ at $15^{\circ} \mathrm{C} / \mathrm{min}$ at interval of $5 \mathrm{~min}$, and the final temperature was kept for
$20 \mathrm{~min}$. Pressure $85.4 \mathrm{kPa}$, the volume of injected sample was 0.2 litre, column flow $1.21 \mathrm{ml} / \mathrm{min}$, total flow $76.8 \mathrm{ml} / \mathrm{min}$, linear velocity $40.5 \mathrm{~cm} / \mathrm{sec}$, purge flow $3.0 \mathrm{ml} / \mathrm{min}$, split ratio: 60.0 ; The MS operating conditions were: $\mathrm{m} / \mathrm{z} 40-600$; ion source temperature $230^{\circ} \mathrm{C}$; and interface line temperature $28^{\circ} \mathrm{C}$. Identification of the compounds: Identification of compounds was based on the interpretation of the mass spectral fragmentation followed by comparing their mass spectra with data from NIST05 (National Institute of Standards and Technology, US) and WILEY 8 libraries by comparing with the MS literature data. ${ }^{33,34}$

\section{RESULTS}

\section{Random Amplified Polymorphic DNA (RAPD) fingerprinting profile}

The genomic DNA isolated from Exacum lawii and purity was $A_{260} / A_{280}$ ratio was found to be 1.6. The DNA was subjected to gel electrophoresis and image was shown if Figure 1. The 6 primers pairs were successfully used for amplification of $m a t K$ and $r b c L$ gene. The primer pair rbcL_1F and rbcL_724R, rbcLaF and rbcLarR and MatK_2.1F and MatK_5R produced two DNA fragments from 700 to $800 \mathrm{bp}$. Figure 1 Table 1.

\section{Pharmacognostical studies \\ Morphological and microscopical}

Exacum lawii are annually grown small erect herb (5-15 cm height) and sometimes branched Figure 2. Leaves are opposite, simple and entire. Upto $6 \mathrm{~mm}$ long, sessile, ovate, acute or subobtuse and 3-5 ribbed. Stem is quadrangular (with 4 wings); slender usually simple and branched near the top. Peduncles are 2 to $5 \mathrm{~cm}$ long, usually one flowered. Infloresence is cymose. Flowers are bisexual and hypogynous. Calyx consists of 4-5 sepals and $4 \mathrm{~mm}$ long, ovate and fused at base. Corolla is purplish blue 6-8 $\mathrm{mm}$ long, 4-5 lobes and overlapping to the right in bud. Androecium: Stamens are 4-5, filament $1.5 \mathrm{~mm}$ long and filiform. Anthers are yellow $1 \mathrm{~mm}$ long and oblong. Gynoecium: Ovary is two celled $0.2-0.4 \mathrm{~cm}$ long and style was long. Ovules many in each cell, stigma is small and sub-capitate. Capsule brown, globose 2 valved capsule $3 \mathrm{~mm}$ diameter. Seeds are minute and sub-cuboid.

Midrib in cross-section showed plano-convex shape with a depression on middle of dorsal side. Epidermis is composed of single layer, thin walled and rectangular shaped cells on upper and lower surface of leaf. Trichomes are absent on either side of epidermis. The vascular bundles projects towards dorsal side. The vessels are arranged in small radial rows. There are circular to isodiametric parenchymatous cells around the vascular bundles. Isobilateral leaf, mesophyll is composed of spongy parenchymatous cells without intercellular space. The mesophyll of lamina consists of 4-6 layered spongy parenchyma. Stomata commonly ranunculaceous usually confined to the lower epidermis of leaf. Figure $3 \mathrm{~A}$. Stem is provided with 4 ribs or wing (quadrangular). The epidermis of stem is papillose and unilayer with compressed isodiametric cells followed with 3-6 layered cortex composed of parenchymatic cells. Cortex is followed by single layer endodermis. Underneath the endodermis there are single layered sclerenchymatic pericyclic cells. Secondary phloem is near pericycle and protoxylem towards pith. Xylem vessels are arranged radially in row towards the pith. Intraxylary phloem is present in the form of continuous ring beneath the vessels. Pith is comprised of rounded or polygonal thin walled parenchymatous cells with no intercellular spaces. Figure 3B

Root system is small and thin. Root hairs are absent. Outer surface consists of single thin layer of epidermal cells. Cortex is multi-layered without intercellular spaces. Endodermis was well distinguished and consisted of longitudinally elongated cells. Secondary xylem is well developed. These cells also showed radial symmetry. Figure $3 \mathrm{C}-3 \mathrm{D}$ 


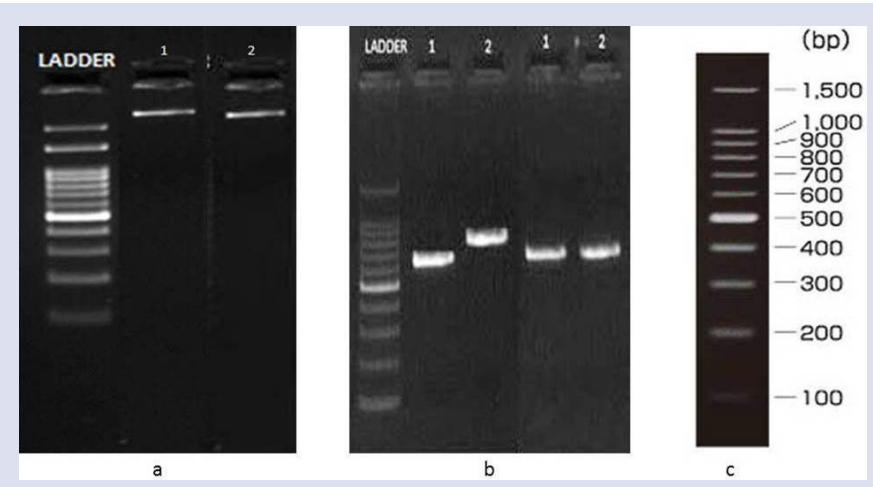

Figure 1: a. Gel electrophoretogram of DNA isolated from Exacum lawii b. The obtained RAPD-PCR products for Exacum lawii showing bands of PCR amplified products of matK and rbcL universal primers. C. specifications of ladder.

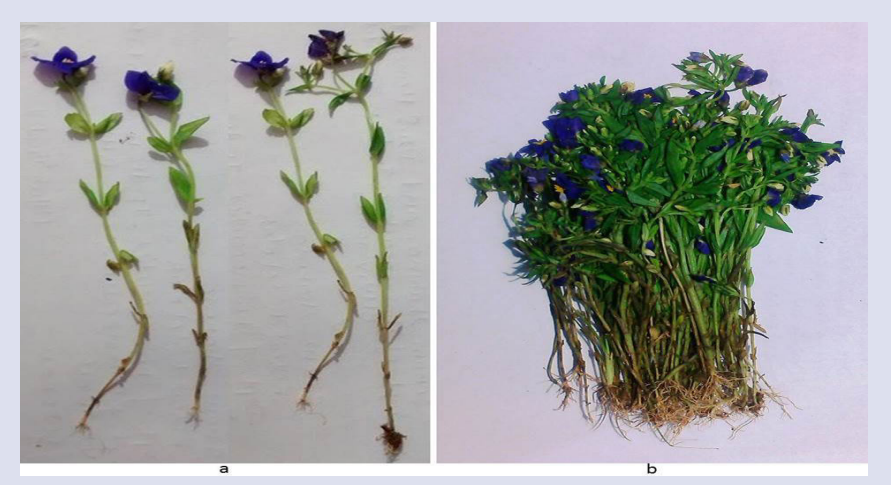

Figure 2: Freshly collected Exacum lawii whole plant.

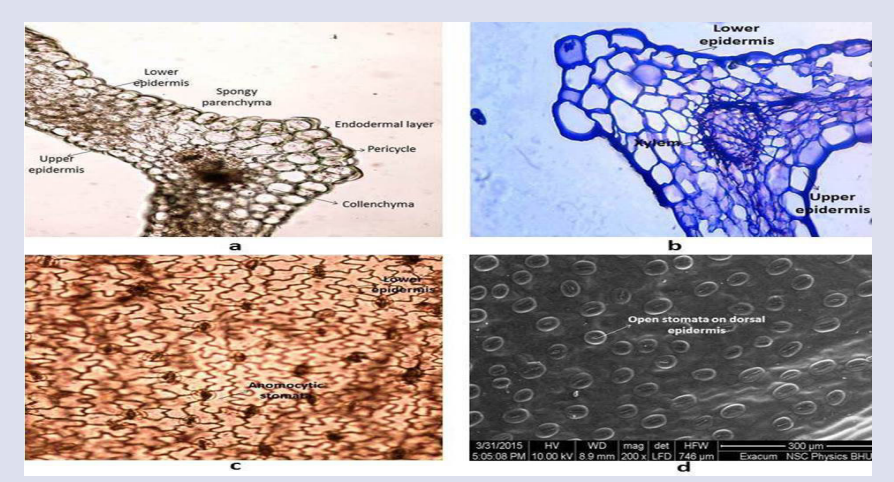

Figure 3A: $a$ and b: Transverse section of midrib, $c$ and d: Stomata on lower epidermis.

\section{Powder microscopy}

Dried powder of whole plant of Exacum lawii was investigated under microscope. Astrosclereides, cell wall was drawn out into lobes to form a more or less stellate body and calcium oxalate crystals which plays defensive role against herbivores were observed. Presence of parenchymatic

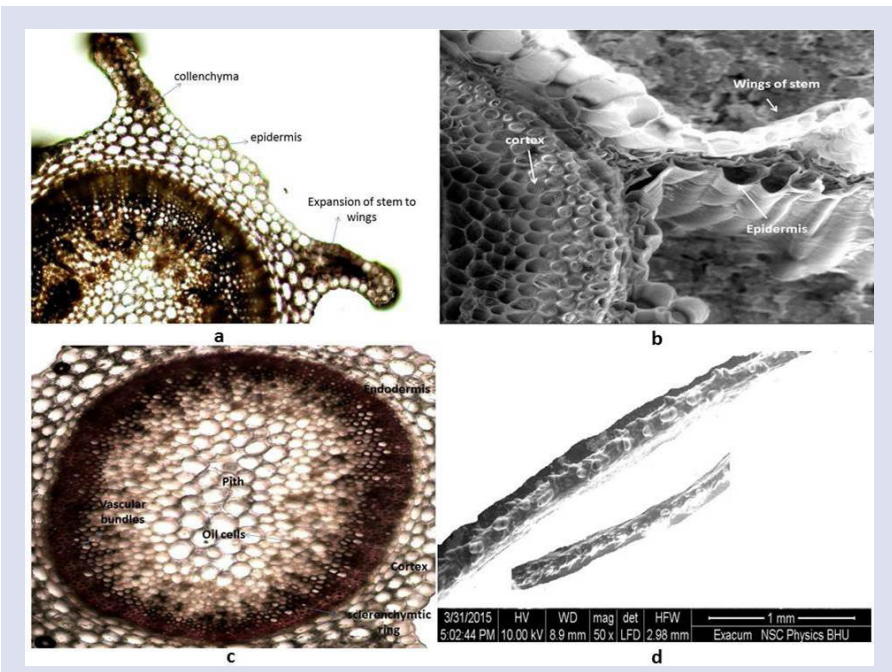

Figure 3B: a. Transverse section of stem showing wings, b. SEM micrograph of stem, c Transverse section of stem showed centre cylinder, d. SEM micrograph of papillose stem.
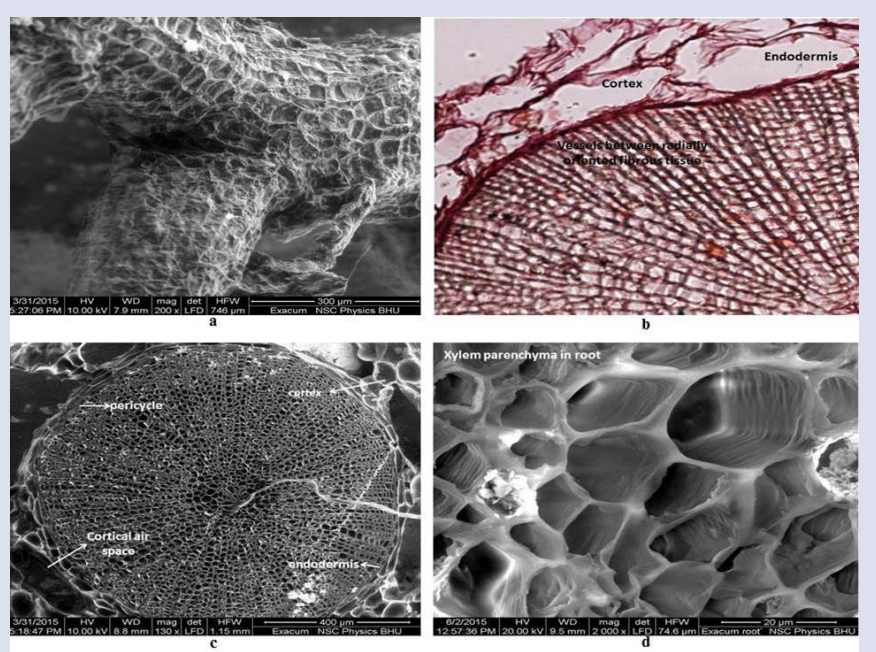

Figure 3C: a. SEM micrograph of root outer surface, b. Transverse section of root cortex, $c$ and $d$. SEM micrograph of root with radial arrangement of xylem vessels.

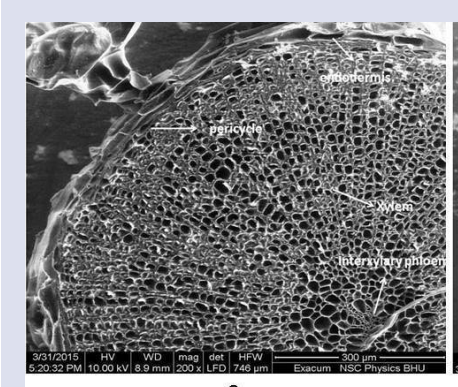

a

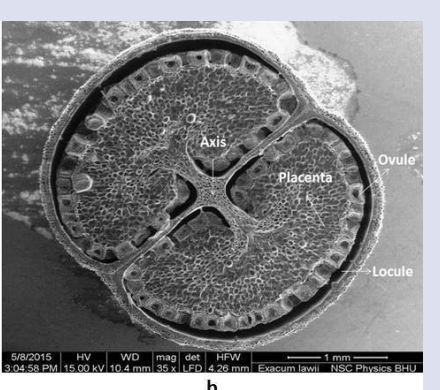

Figure 3D: a: SEM micrograph of root b: SEM micrograph of ovary. 
Table 1: Primers used for amplification of matK and rbcL gene segments.

\begin{tabular}{cccc}
\hline Primer name & Primer set & Binding & Primer sequence $\left(5^{\prime}-3^{\prime}\right)$ \\
\hline matK-2.1F & matK-A & Forward & CCTATCCATCTGGAAATCTTAG \\
matK-5R & & Reverse & GTTCTAGCACAAGAAAGTCG \\
rbcLaF & rbcL-A & Forward & ATGTCACCACAAACAGAGACTAAAGC \\
rbcLaR & & Forward & GTAAAATCAAGTCCACCRCG \\
rbcL-1F & rbcL-B & Reverse & ATGTCACCACAAACAGAAAC \\
rbcL-724R & & Reverse & TCGCATGTACCTGCAGTAGC \\
\hline
\end{tabular}

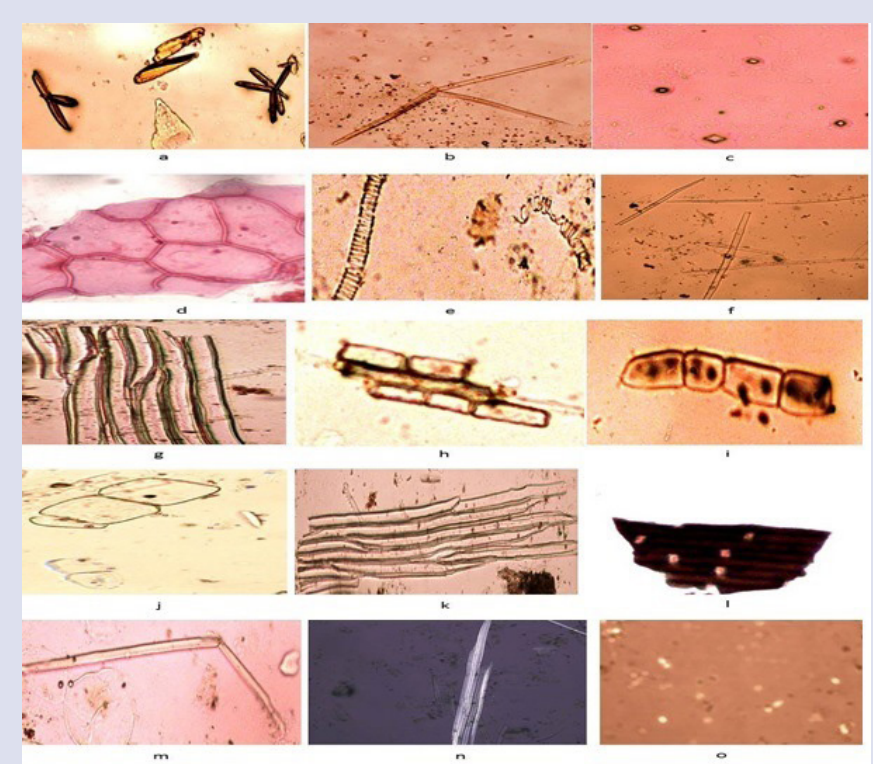

Figure 4: a. Astrosclereides, b. Needle shaped raphides, c. Tetragonal calcium oxalate crystals, d. Epidermal cells, e. spiral thickening of xylem vessels, f. narrow fibres, g. Parenchyma in cortex, h. parenchyma cell, i. sclereids, j. lignified pitted parenchyma, k. fibres and sclereids, I. cork cells, m. septate fibre, n. phloem fibre, o. starch grain.

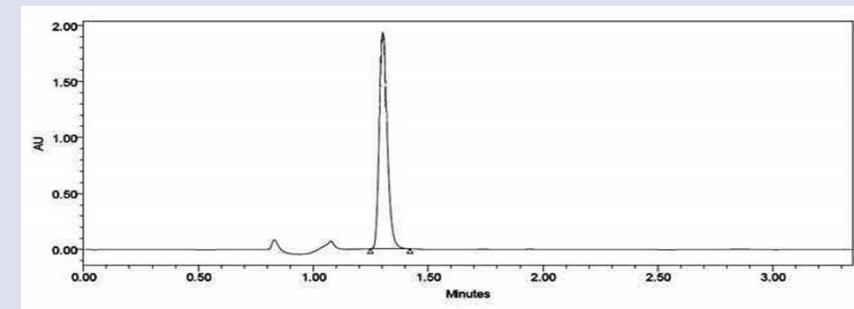

a.

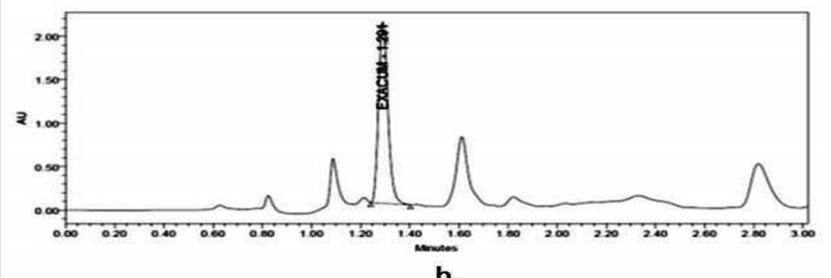

b.

Figure 5: a. HPLC chromatogram showing peak of standard Swertiamerin, b. HPLC chromatogram of ethanolic extract of Exacum lawii showing peak of Swertiamerin.
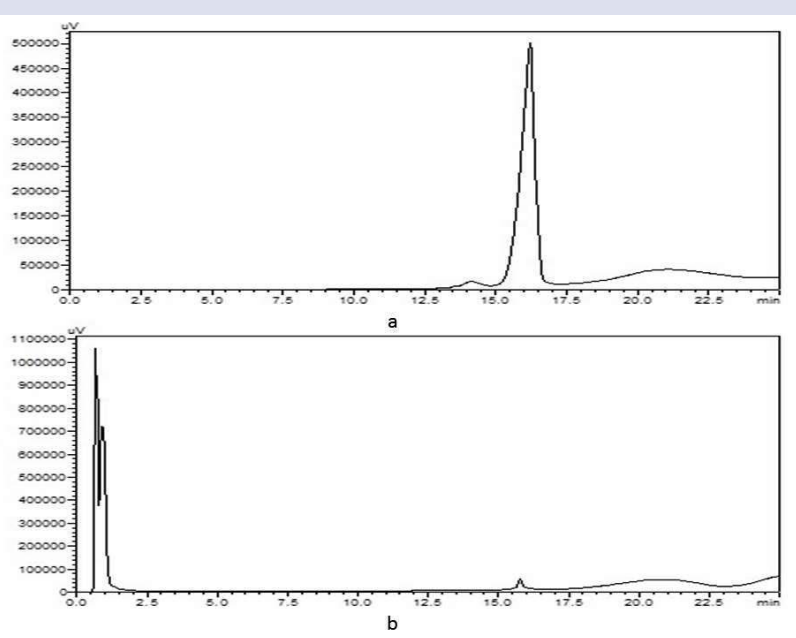

Figure 6: a. HPLC chromatogram showing peak of standard Ursolic acid, b. HPLC chromatogram of ethanolic extract of Exacum lawii showing peak of Ursolic acid.

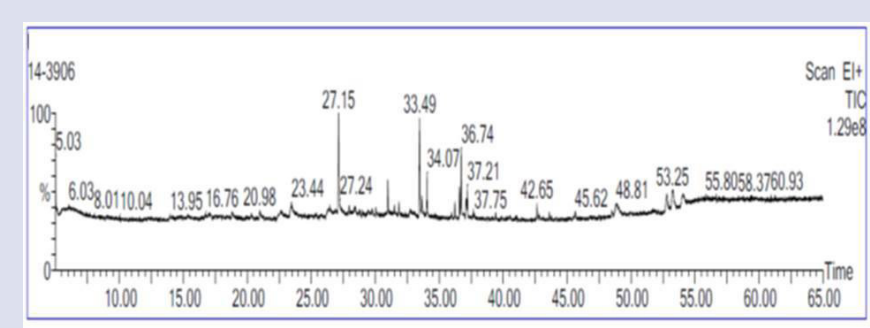

Figure 7: GC-MS chromatogram of ethanolic extract of Exacum lawii.

cells, brick shaped cork cells and epidermal cells, spiral xylem vessels, phloem fibres, narrow fibres and starch grains were confirmed Figure 4.

\section{Quantitative microscopy}

Quantitative microscopy is useful for fixing standards for crude drugs. Values of different leaf constants are as follows Stomatal number (upper and lower) was $140-180$ per $\mathrm{mm}^{2}$ and $150-250$ per $\mathrm{mm}^{2}$ respectively, Stomatal index (upper and lower) was 15.5-18.5 and 21.5- 25.5 respectively, Vein islet number was $8.6-12.8$ per $\mathrm{mm}^{2}$ and Vein termination number was 9.2-13.1 per $\mathrm{mm}^{2}$.

\section{Nutritional content analysis and physicochemical}


Table 2: Nutritional content analysis.

\begin{tabular}{|c|c|c|}
\hline Vitamins & Methods & Results \\
\hline Vitamin $\mathrm{E}$ & AOAC 2001.13 & $5.06 \mathrm{mg} / 100 \mathrm{~g}$ \\
\hline Vitamin A & AOAC 2001.13 & $<100.0 \mathrm{IU} / 100 \mathrm{~g}$ \\
\hline Vitamin C & AOAC 2012.21 & $6.11 \mathrm{mg} / 100 \mathrm{~g}$ \\
\hline \multicolumn{3}{|l|}{ Minerals } \\
\hline Calcium $(\mathrm{Ca})$ & AOAC2011.14 & $12871.67 \mathrm{mg} / \mathrm{kg}$ \\
\hline Potassium (K) & AOAC2011.14 & $8041.58 \mathrm{mg} / \mathrm{kg}$ \\
\hline Sodium (Na) & AOAC2011.14 & $6196.54 \mathrm{mg} / \mathrm{kg}$ \\
\hline \multicolumn{3}{|l|}{ Fatty acid profile } \\
\hline Saturated fatty acids (total) & AOAC 996.01 & $2.03 \mathrm{~g} / 100 \mathrm{~g}$ \\
\hline Monounsaturated fatty acids (total) & AOAC 996.01 & $1.21 \mathrm{~g} / 100 \mathrm{~g}$ \\
\hline Polyunsaturated fatty acids (total) & AOAC 996.01 & $1.19 \mathrm{~g} / 100 \mathrm{~g}$ \\
\hline homo-gamma-Linolenic & & $<0.1 \mathrm{~g} / 100 \mathrm{~g}$ \\
\hline Caproic acid & & $<0.1 \mathrm{~g} / 100 \mathrm{~g}$ \\
\hline Caprylic acid & & $<0.1 \mathrm{~g} / 100 \mathrm{~g}$ \\
\hline Capric acid & & $<0.1 \mathrm{~g} / 100 \mathrm{~g}$ \\
\hline Undecanoic acid & & $<0.1 \mathrm{~g} / 100 \mathrm{~g}$ \\
\hline Lauric acid & & $<0.1 \mathrm{~g} / 100 \mathrm{~g}$ \\
\hline Tridecanoic acid & & $<0.1 \mathrm{~g} / 100 \mathrm{~g}$ \\
\hline Myristic acid & & $<0.1 \mathrm{~g} / 100 \mathrm{~g}$ \\
\hline Myristoleic acid & & $<0.1 \mathrm{~g} / 100 \mathrm{~g}$ \\
\hline Pentadecanic acid & & $<0.1 \mathrm{~g} / 100 \mathrm{~g}$ \\
\hline Linolelaidic acid & & $<0.1 \mathrm{~g} / 100 \mathrm{~g}$ \\
\hline alpha-Linolenic acid & & $0.76 \mathrm{~g} / 100 \mathrm{~g}$ \\
\hline Arachidic acid & & $<0.1 \mathrm{~g} / 100 \mathrm{~g}$ \\
\hline Eicosenoic acid & & $<0.1 \mathrm{~g} / 100 \mathrm{~g}$ \\
\hline Eicosadienoic acid & & $<0.1 \mathrm{~g} / 100 \mathrm{~g}$ \\
\hline Eicosatrienoic acid & & $<0.1 \mathrm{~g} / 100 \mathrm{~g}$ \\
\hline Aracidonic acid & & $<0.1 \mathrm{~g} / 100 \mathrm{~g}$ \\
\hline Eicosapentaenic acid & & $<0.1 \mathrm{~g} / 100 \mathrm{~g}$ \\
\hline Heneicosanoic acid & & $<0.1 \mathrm{~g} / 100 \mathrm{~g}$ \\
\hline Behenic acid & & $<0.1 \mathrm{~g} / 100 \mathrm{~g}$ \\
\hline Docosenoic acid + isomers & & $<0.1 \mathrm{~g} / 100 \mathrm{~g}$ \\
\hline Docosadienoic acid & & $<0.1 \mathrm{~g} / 100 \mathrm{~g}$ \\
\hline Docosahexaenic acid & & $<0.1 \mathrm{~g} / 100 \mathrm{~g}$ \\
\hline Tricosanoic acid & & $<0.1 \mathrm{~g} / 100 \mathrm{~g}$ \\
\hline Lignoceric acid & & $<0.1 \mathrm{~g} / 100 \mathrm{~g}$ \\
\hline Nervonic acid & & $<0.1 \mathrm{~g} / 100 \mathrm{~g}$ \\
\hline Elaidic acid & & $<0.1 \mathrm{~g} / 100 \mathrm{~g}$ \\
\hline Gamma-Linolenic acid & & $<0.1 \mathrm{~g} / 100 \mathrm{~g}$ \\
\hline
\end{tabular}


Table 3: Physicochemical parameters of Exacum lawii.

\begin{tabular}{|c|c|c|c|c|}
\hline S.No. & Quantitative standards & & & Observation \\
\hline 1 & ${ }^{*}$ Moisture content & & & $6.10 \% \mathrm{w} / \mathrm{w}$ \\
\hline 2 & ${ }^{\star}$ Swelling index & & & $0.89 \% \mathrm{w} / \mathrm{v}$ \\
\hline 3 & Foaming index & & & $<100$ \\
\hline 4 & ${ }^{\star}$ Total ash & & & $6.06 \% \mathrm{w} / \mathrm{w}$ \\
\hline 5 & ${ }^{\star}$ Acid insoluble ash & & & $1.26 \% \mathrm{w} / \mathrm{w}$ \\
\hline 6 & ${ }^{*}$ Water soluble ash & & & $2.49 \% \mathrm{w} / \mathrm{w}$ \\
\hline 7 & ${ }^{\star}$ Bulk density & & & $0.59 \% \mathrm{w} / \mathrm{w}$ \\
\hline 8 & ${ }^{\star}$ Foreign matter & & & $<0.5 \% \mathrm{w} / \mathrm{w}$ \\
\hline 9 & Volatile oil content & & & $0.10 \%$ yield ( $\mathrm{ml} / 100 \mathrm{gm}$ of dry weight) \\
\hline 10 & ${ }^{*}$ Crude fibre content & & & $34.9 \% \mathrm{w} / \mathrm{w}$ \\
\hline \multirow[t]{5}{*}{11} & Heavy metal content & $\lambda_{\max }$ & Fuel flowrate(1/min) & Concentrations in PPM \\
\hline & Lead $(\mathrm{Pb})$ & 282.3 & 2.0 & Not more than $0.010 \mathrm{PPM}$ \\
\hline & Cadmium $(\mathrm{Cd})$ & 228.7 & 1.8 & Not more than 0.0002 PPM \\
\hline & Zinc $(\mathrm{Zn})$ & 211.9 & 2.0 & Not more than 0.235 PPM \\
\hline & Mercury (Hg) & 253.5 & 1.8 & Not more than 0.220 PPM \\
\hline
\end{tabular}

*Values are mean \pm SEM, $(\mathrm{n}=3)$

Table 4: Quantitative estimation of various classes of phytochemical compound.

\begin{tabular}{cccccc}
\hline Extracts & $\begin{array}{c}\text { Extractive } \\
\text { value(\%w/w) }\end{array}$ & $\begin{array}{c}\text { Phenolic content } \\
(\mathbf{m g ~ G A E} / \mathbf{g m})\end{array}$ & $\begin{array}{c}\text { Flavonoid } \\
\text { content } \\
(\mathbf{m g} \text { rutin/gm) }\end{array}$ & $\begin{array}{c}\text { Flavonol content } \\
\text { (mg rutin/gm })\end{array}$ & $\begin{array}{c}\text { Alkaloidal content } \\
(\mathbf{m g} / \mathbf{g m})\end{array}$ \\
\hline Ethanol extract & $10.70 \% \mathrm{w} / \mathrm{w}$ & $12.21 \pm 0.58$ & $21.86 \pm 0.22$ & $15.53 \pm 0.05$ & $35.59 \pm 0.13$ \\
Petroleum ether fraction & $8.48 \% \mathrm{w} / \mathrm{w}$ & $1.45 \pm 0.15$ & $1.56 \pm 0.10$ & $0.91 \pm 0.02$ & $6.53 \pm 0.15$ \\
Toluene fraction & $9.30 \% \mathrm{w} / \mathrm{w}$ & $3.38 \pm 0.14$ & $3.24 \pm 0.04$ & $1.32 \pm 0.08$ & $8.10 \pm 0.10$ \\
Chloroform fraction & $4.56 \% \mathrm{w} / \mathrm{w}$ & $6.82 \pm 0.16$ & $18.29 \pm 0.07$ & $8.46 \pm 0.2$ & $12.39 \pm 0.15$ \\
Ethyl acetate fraction & $1.98 \% \mathrm{w} / \mathrm{w}$ & $8.33 \pm 0.10$ & $6.55 \pm 0.12$ & $5.5 \pm 0.10$ & $26.29 \pm 0.16$ \\
Aqueous fraction & $12.65 \% \mathrm{w} / \mathrm{w}$ & $8.34 \pm 0.16$ & $9.33 \pm 0.08$ & $10.1 \pm 0.32$ & $15.5 \pm 0.12$ \\
\hline
\end{tabular}

Each column represents as means $\pm \mathrm{SD}(\mathrm{n}=6)$

\section{evaluation}

The whole plant of Exacum lawii was dried in shade in room temperature for analysis of vitamins. The results were expressed as mg of element per $100 \mathrm{gm}$ of dry weight plant material. From the results vitamin $\mathrm{C}$ was found to be in higher amount $6.11 \mathrm{mg} / 100 \mathrm{gm}$ as ascorbic acid. The calcium content $(12871.67 \mathrm{mg} / \mathrm{kg})$ was found to be in appreciative quantitative in comparison with other macro-elements. It showed Exacum lawii can be a good source of calcium. Fatty acid profile showed different concentration of saturated fatty acids, polyunsaturated fatty acids, monounsaturated fatty acids, trans-fatty acids. Palmitic acid (1.37 gm/100 gm), Stearic acid (0.41 gm/100 gm), Oleic acid (0.41 $\mathrm{gm} / 100 \mathrm{gm})$, Linoleic acid (1.11 gm/100 gm) and alpha-Linolenic acid $(0.76 \mathrm{gm} / 100 \mathrm{gm})$ along with other fatty acids. Energy in calories was estimated to be $44.73 \mathrm{kcal} / 100 \mathrm{gm}$ Table 2 . The results for the quantitative physicochemical constants of the air dried powder material were represented in the Table 3.

\section{Pesticide residue and heavy metal estimation}

The chlorinated pesticide present in the whole plant of Exacum lawii in first and the second elute was reported to be $0.023 \pm 0.001 \mathrm{mg} / \mathrm{kg}$ and $0.012 \pm 0.00 \mathrm{mg} / \mathrm{kg}$ of plant material. The phosphate pesticide from the first and second elute of column was found to be $0.021 \pm 0.001 \mathrm{mg} / \mathrm{kg}$ and $0.018 \pm 0.001 \mathrm{mg} / \mathrm{kg}$ of plant material respectively. While in third elute pesticide content was reported to be absent. Heavy metals content (in PPM) were calculated and given in Table 3. The values were found to be within the limit as prescribed by the WHO guidelines.

\section{Phytochemical screening \\ Preliminary Phytochemical screening}

Phytochemical investigation indicated the presence of alkaloids, flavonoids, phenolic compounds, terpenoids, steroids and coumarins with in ethanolic extract and its toluene fraction, chloroform fraction, ethyl acetate fraction and. Tannins are found to be present in ethanolic extract and aqueous fraction.

\section{Quantitative phytochemical estimation}

The total phenolic content, Flavonoid content, Flavonol content and Alkaloidal content of ELE and its different fractions are given in Table 4.

\section{HPLC quantification of Swertiamerin and Ursolic acid}

Chromatograms of ELE along with standard Swertiamarin and Ursolic acid have been shown in Figure 5 and 6. Mean retention time was of $1.3 \mathrm{~min}$ 
Table 5: Major compounds identified by GCMS in ethanolic extract of Exacum lawii.

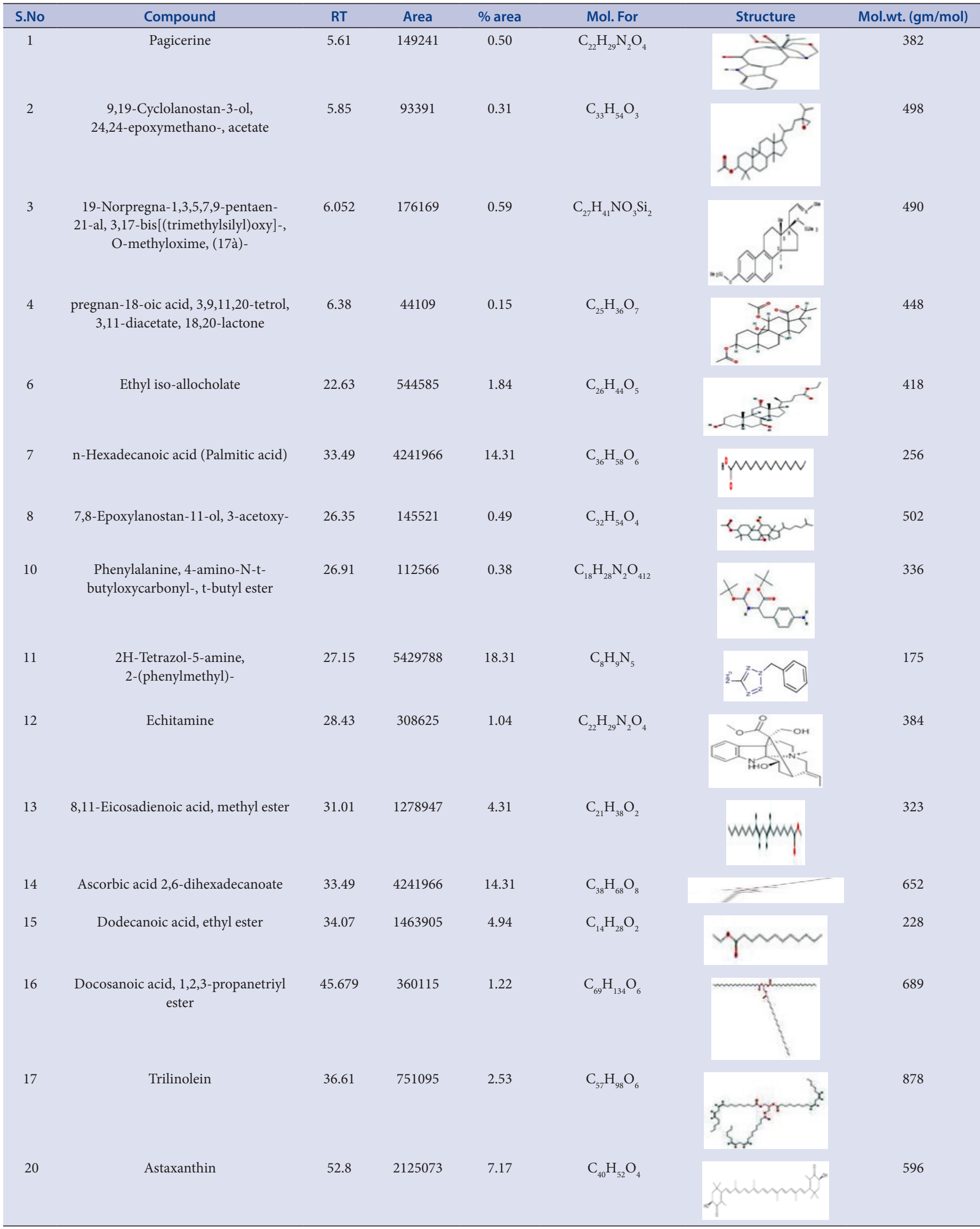


16 min. The concentration of swertiamarin in ELE was found to be $119.59 \mathrm{mg} / \mathrm{gm}$. Mean retention time for Ursolic acid was found to be $1.6 \mathrm{~min}$ and concentration of Ursolic acid calculated was $5.34 \mathrm{mg} / \mathrm{gm}$ of ELE. Figure 5,6

\section{Extract composition by GCMS analysis}

GC-MS analysis of ELE led to the identification of 20 compounds. The chromatogram is shown in Figure 7 and identified compounds were listed in table along with retention time, peak area, peak percentage area and molecular weight Table 5.

\section{DISCUSSION}

Despite of extensive medicinal uses of Exacum lawii mention in literature, there is no information on physicochemical or phytochemical parameters are reported to justify the quality control profile of Exacum lawii. Standardization of herbal drugs using analytical techniques could be the major and accurate step in their proper authentication.

DNA markers are more authentic for identification as the genetic information of each species is its unique characteristic and is independent of environmental factors, physiological conditions and other subjective errors. A number of molecular tools are available to establish DNA fingerprinting profiles like RFLP, AFLP, RAPD and SSR. In the RAPD method, random short synthetic oligonucleotide primers are used to amplify the genomic DNA through polymerase chain reaction under low annealing temperature up to $28^{\circ} \mathrm{C}-38^{\circ} \mathrm{C}$. The DNA fragments generated are separated on agarose gels based on sizes and compared with marker. ${ }^{35}$ In the present study 2 gene combination of ribulose-1, 5-bisphosphate carboxylase oxygenase large subunit ( $\mathrm{rbcL}$ ) and maturase $\mathrm{K}$ (matK) as the standard plant barcode were chosen. ${ }^{36}$ These two loci of chloroplast DNA were taken due to their efficient recovery of good quality sequences and high levels of species discrimination. ${ }^{37}$

Nutritional content analysis identified Exacum lawii as a rich source of vitamin $\mathrm{C}$ or ascorbic acid which acts as an antioxidant, which protects the body from oxidative stress and maintains the immune system. In addition, it also prevents damage to lipids, protein and DNA by neutralising free radicals. ${ }^{38}$ Vitamin A (retinoic acid), it is a bioactive metabolite and a potent signalling molecule in the brains which modulates neurogenesis, neuronal survival, synaptic plasticity and regulates numerous gene products. ${ }^{39}$ Vitamin $\mathrm{E}$ is the major component of the cell antioxidant defence system and has numerous important roles in the body due to its antioxidant activity. ${ }^{40}$ The most abundant macroelements detected were Calcium (Ca), Potassium (K), Iron $(\mathrm{Fe})$ and Sodium (Na). Nutritional analysis of fatty acids can be classified as qualitative and quantitative. Qualitative analysis of fatty acid ensures the fatty acid composition and quantitative analysis is to quantify the actual amount of each fatty acid that is present in the plant material. Exacum lawii contains rich concentration of polyunsaturated and monounsaturated fatty acid among which alpha-linolenic acid, linoleic acid and oleic acid were found to be in higher content. Fatty acids can classified as bad and good fatty acids. Bad fatty acids are saturated and trans-fatty acids which increase total cholesterol and LDL levels. Good fatty acids are monounsaturated and polyunsaturated fatty acids, which can play the role in many therapeutic activities. ${ }^{41,42}$

Physicochemical parameters serve as a valuable source of information for the identification of plant material from other closely related Exacum species. It also provides suitable standards to determine the quality and purity of the plant. The results showed the presence of very less moisture content in plant. Since higher moisture content in plant material may lead to its deterioration and may lead to hydrolysis of active constituents. The ash values represent inorganic salts occurring naturally or deliberately added to crude drug as a form of adulterant. Total ash in a plant material includes both physiological as well as non-physiological ash. Acid insoluble ash and water soluble ash values quantify the inorganic material and silica respectively. From the results, it was found that the Exacum lawii showed the presence of higher quantity of water soluble ash compared to acid insoluble ash. Swelling index of a plant material is pharmaceutical value which denotes the presence of gums, mucilage, pectin and hemicelluloses. ${ }^{43,44}$ All the physicochemical parameters were standardised and documented with their estimated limits present.

The bioactive constituents of medicinal plants like alkaloids, tannins, steroids, terpenoids and phenolics are responsible for their therapeutic activity. ${ }^{45}$ Preliminary phytochemical screening and TLC analysis confirms that ethanolic extracts of Exacum lawii and its fractions contain terpenoids, polyphenols, flavonoids, alkaloids and steroids. The ethanolic extract of Exacum lawii quantifies higher number of phytocompounds. Swertiamerin, is bitter secoiridoid glycoside found in various species of family gentianaceae and have been reported to possess anti-edematogenic, antioxidant, hepatoprotective, anti-inflammatory, anti-nociceptive, anti-hyperlipidimic and analgesic. ${ }^{46,51}$ Ursolic acid (3 $\beta$-hydroxy-urs-12ene-28-oic acid) is a pentacyclic terpenoid, present in plants as secondary plant metabolite. Phytochemical makers swertiamerin and ursolic acid were quantified by using HPLC. There are many pharmacological properties of ursolic acid like anti-cancer activity, hepatoprotective, neuroprotective, cardioprotective, nephroprotective, antimicrobial and antiviral activity. ${ }^{52-53}$ GC-MS is an analytical technique used to separate and identify compounds that can be vaporised without decomposition. In present study, GC-MS analysis of ELE revealed 22 compounds with their molecular weight, peak area and retention time. Compound found with highest peak area percentage (18.31) was $2 \mathrm{H}$-Tetrazol-5-amine, 2-(phenylmethyl). Tetrazole and tetrazole derivative have diverse biological activities like hypotensive, antimicrobial, antiviral, antiallergic, cytostatic, nootropic, and other biological activities. ${ }^{54}$ Ascorbic acid 2, 6-dihexadecanoate was found as next dominant component with peak area percentage 14.31 and has been reported to have antioxidant, antiinflammatory and anti-nociceptive properties. ${ }^{55,56}$ Astaxanthin, a naturally occurring terpenoid compound with peak area percentage 7.17 was also detected. ${ }^{57}$ Echitamine a monoterpene indole alkaloid (peak area percentage 1.04) was confirmed along with some polyunsaturated fatty acids. The compounds identified may play very essential role in diverse therapeutic activity.

\section{CONCLUSION}

In conclusion all-inclusive results obtained from DNA fingerprinting, pharmacognostical and phytochemical standardization become important source to scientifically develop the quality control standards of Exacum lawii. These standards will ensure the authenticity and therefore assist in retaining medicinal importance of Exacum lawii.

\section{ACKNOWLEDGEMENT}

Department of Pharmaceutics, IIT (B.H.U) Varanasi is highly acknowledged for providing financial support to Ms Sonam Sharma as Teaching Assistantship.

\section{CONFLICTS OF INTEREST}

The author reports no conflicts of interest.

\section{ABBREVIATIONS USED}

RAPD: Random amplified polymorphic DNA; AOAC: Association of Official Analytical Chemists; WHO: World health organization; GCMS: Gas chromatography mass spectrometry; HPLC: High-performance 
liquid chromatography; PCR: Polymerase chain reaction; SEM: scanning electron microscope.

\section{REFERENCES}

1. Jouad H, Haloui M, Rhiouani H, El Hilaly J, Eddouks M. Ethnobotanical survey of medicinal plants used for the treatment of diabetes, cardiac and renal diseases in the North centre region of Morocco (Fez-Boulemane). Journal of Ethnopharmacology. 2001;77(2):175-82.

2. Demiray S, Pintado ME, Castro PM. Evaluation of phenolic profiles and antioxidant activities of Turkish medicinal plants: Tilia argentea, Crataegi folium leaves and Polygonum bistorta roots. World Academy of Science, Engineering and Technology. 2009;54:312-7.

3. Hooker JD. The Flora of British India. L. Reeve and Co. London;1885.

4. Gamble JS. The Flora of Presidency of Madras. Adlard and Son Ltd. London. $1923 ; 2: 612-5$

5. Kirtikar KR and Basu BD. Indian Medicinal Plants. Bishen Singh Mahendra Pal Singh, Allahabad. 1935;3(2):1654-5.

6. Chopra RN, Nayar SL, Chopra IC, Asolkar LV and Kakkar KK. Glossary of Indian medicinal plants. New Delhi: Council of Scientific and Industrial Research. 1956:116.

7. Linnaeus C. Dissertatio Dassow. C.M. Nova Plantarum Genera, Stockholm, Sweden; 1747 .

8. Linnaeus C. Flora Zeylanica. Sumtu et Literis Laurentii Salvii, Holmiae; 1747b.

9. Struwe L, Hagen KB, Kadereit JW, Klackenberg J, Nilsson JS. Systematics, character evolution, and biogeography of Gentianaceae, including a new tribal and subtribal classification. In: Struwe L, Albert V.A. (eds). GentianaceaeSystematics and natural history. Cambridge University Press, Cambridge. 2002

10. Clarke CB. Gentianaceae In: J.D. Hooker (ed). 1883.

11. Damaji $B$ and KhandekarVP. Endemic plants of Maharashtra state at Jarandeshwar hill of Satara district (Maharashtra). Indian Streams Research Journal. 2011;1:1-3.

12. Vinayaka KS, Ashwini HS, Prashith KTR, Krishanamurthy YL. Traditional utilization and phytochemical analysis of medicinal herb Exacum Linn. From central Western Ghats. Asian Pacific Journal of Health Sciences. 2016;3(1):161-4

13. Mallikarjuna MB, Sheriff A and Krishnappa DG. Exacum lawii C.B. Clarke. Chromosome Number Reports 97. Taxon 36. 1987;766-7.

14. Mallikarjuna, MB. Karyomorphological and cytotaxonomic studies in the family Gentianaceae. Ph.D. Thesis, Bangalore University. 1985.

15. Bafeel SO, Arif IA, Bakir MA, Al Homaidan AA, Al Farhan AH. DNA barcoding of arid wild plants using rbcL gene sequences. Genet. Mol. Res. 2012;11(3):1934-41.

16. Sameera OB, Ibrahim AA, Mohammad AB, Haseeb AK, Farhan AH. Comparative evaluation of PCR success with universal primers of maturase $K$ (matK) and ribulose-1, 5-bisphosphate carboxylase oxygenase large subunit ( $r b c L$ ) for barcoding of some arid plants. Plant Omics. 2011;4(4):195-8.

17. Evans WC. Trease and Evans Pharmacognosy, 15th ed. Edinburgh:W B Saunders; 2002.

18. Khandelwal KR. Practical Pharmacognosy, Techniques and Experiments. 17th ed: Nirali Prakashan Pune, India. 2007.

19. Brain KR, Turner TD. The Practical Evaluation of Phytopharmaceuticals. Bristol: Wright-Scientechnica. 1975;36-45.

20. Johansen DA. Plant microtechnique. McGraw-Hill Book Company, Inc: London; 530p;1940.

21. Laloo D, Kumar M, Prasad SK, Hemalatha S. Quality control standardization of the roots of Potentilla fulgens Wall. A potent medicinal plant of the Western Himalayas and North-eastern India. Pharmacognosy Journal. 2013;5(3):97-103.

22. Horwitz W. Official methods of analysis of AOAC international. 17th edition: USA: Association of Official Analytical Communities. 2003.

23. Anonymous, Quality Control Methods for Medicinal Plant Materials (World Health Organization), Geneva. Delhi: A.I.T.B.S. Publishers and Distributors; 2002.

24. Gomez MR, Cerutti S, Sombra LL, Silva MF, Martínez LD. Determination of heavy metals for the quality control in argentinian herbal medicines by ETAAS and ICP-OES. Food and Chemical Toxicology. 2007;45(6):1060-4.

25. Evans WC: Trease and Evans Pharmacognosy. Edinburgh: W. B. Saunders, 15th edition. 2002

26. Harbone JB: Phytochemical Methods. 3rd ed; London, Chapman Hall. 1984.

27. Prasad SK, Laloo D, Kumar M, Hemalatha S. Quality control standardization and antioxidant activity of roots from Eriosema chinense. Pharmacognosy Journal. 2013;5(4):149-55.

28. Grubešic RJ, Vukovic J, Kremer D, Vladimir-Kneževic S. Spectrophotometric method for polyphenols analysis: Prevalidation and application on Plantago L. species. Journal of Pharmaceutical and Biomedical analysis. 2005;39(3):837-42.

29. Kumaran A, Karunakaran RJ. In vitro antioxidant activities of methanol extracts of five Phyllanthus species from India. LWT-Food Science and Technology. 2007;40(2):344-52.

30. John BI, Sulaiman CT, George S, Reddy VR. Spectrophotometric estimation of total alkaloids in selected Justicia species. International journal of pharmacy and pharmaceutical sciences. 2014;6(5):647-8.
31. Rana VS, Dhanani T and Kumar S. Improved and rapid HPLC-PDA method for identification and quantification of swertiamarin in the aerial parts of Enicostemma axillare. Malaysian J Pharma Sc. 2012;10(1):1-10.

32. Taralkar SV and Chattopadhyay S. A HPLC Method for Determination of Ursolic Acid and Betulinic Acids from their Methanolic Extracts of Vitex negundo Linn. J Anal Bioanal Techniques. 2012;3(3):1-6.

33. Jennings $W$ and Shibamoto T. Qualitative analysis of flavour and fragrance volatile by glass capillary gas chromatography. Academic press, Inc., New York; 1980

34. Adams RP. Identification of essential oil components by GC-MS. Allured Publishing Corp. Carol Stream, Illinois, USA;2007.

35. Ganie SH, Upadhyay P, Das S, Sharma MP. Authentication of medicinal plants by DNA markers. Plant Gene. 2015;4:83-99.

36. Group CP, Hollingsworth PM, Forrest LL, Spouge JL, Hajibabaei M. A DNA barcode for land plants. Proceedings of the National Academy of Sciences. 2009;106(31):12794-7.

37. Burgess KS, Fazekas AJ, Kesanakurti PR, Graham SW, Husband BC. Discriminating plant species in a local temperate flora using the $r b c L+$ matK DNA barcode. Methods in Ecology and Evolution. 2011;2(4):333-40.

38. Wilson T. Antioxidants, Human Health and Health Diseases. Wallingford, United Kingdom: Cabi Publishing. Whole foods, antioxidants and health. 1999;141-50.

39. Olson CR, Mello CV. Significance of vitamin A to brain function, behavior and learning. Molecular nutrition and food research. 2010;54(4):489-95.

40. Rizvi S, Raza ST, Ahmed F, Ahmad A, Abbas S, Mahdi F. The role of vitamin E in human health and some diseases. Sultan Qaboos University Medical Journal. 2014;14(2):e157.

41. Abd-Aziz N, Azlan A, Ismail A, Mohd-Alinafiah S, Razman MR. Quantitative determination of fatty acids in marine fish and shellfish from warm water of Straits of Malacca for nutraceutical purposes. BioMed research international. 2012;2013.

42. Zevenbergen $H$, Bree DA, Zeelenberg M, Laitinen K, Van DG. Foods with a high fat quality are essential for healthy diets. Annals of Nutrition and Metabolism. 2009;54(1):15-24.

43. Prasad SK, Sahu AN, Hemalatha S. Cytomorphological and physicochemical evaluations of Cryptocoryne spiralis. Journal of herbs, spices and medicinal plants. 2012;18(4):304-17.

44. Anonymous. Quality Control Methods for Medicinal Plant Materials (An Authorized Publication of World Health Organization, Geneva). Delhi: A.I.T.B.S. Publishers and Distributors (Regd); 2002.

45. Paul C, Chikezie, Chiedozie O and Mbagwu N. Bioactive Principles from Medicinal Plants. Research Journal of Phytochemistry. 2015;9:88-115.

46. Jaishree $\mathrm{V}$, Badami S. Antioxidant and hepatoprotective effect of swertiamarin from Enicostemma axillare against d-galactosamine induced acute liver damage in rats. Journal of ethnopharmacology. 2010;130(1):103-6.

47. Vaijanathappa J, Badami S. Antiedematogenic and free radical scavenging activity of swertiamarin isolated from Enicostemma axillare. Planta medica. 2009;75(01):12-7.

48. Vaijanathappa J, Badami S, Bhojraj S. In vitro antioxidant activity of Enicostemma axillare. Journal of health science. 2008;54(5):524-8.

49. Jaishree V, Badami S, Kumar MR, Tamizhmani T. Antinociceptive activity of swertiamarin isolated from Enicostemma axillare. Phytomedicine. 2009; 16(2):227-32.

50. Vaidya H, Rajani M, Sudarsanam V, Padh H, Goyal R. Swertiamarin: A lead from Enicostemma littorale Blume. for anti-hyperlipidaemic effect. European journal of pharmacology. 2009;617(1):108-12.

51. Lei WY. Swertiamarin's central inhibitory effect. Journal of Chinese Materia Medica 1982;13(8):368.

52. Wozniak $七$, Skapska S, Marszałek K. Ursolic acid a pentacyclic triterpenoid with a wide spectrum of pharmacological activities. Molecules. 2015;20(11):20614-41.

53. Ikeda Y, Murakami A, Ohigashi H. Ursolic acid: An anti-and pro-inflammatory triterpenoid. Molecular nutrition and food research. 2008;52(1):26-42.

54. Ostrovskii VA, Trifonov RE, Popova EA. Medicinal chemistry of tetrazoles. Russian Chemical Bulletin. 2012;61(4):768-80.

55. Akinmoladun AC, Ibukun EO, Afor E, Akinsinlola BL, Onibon TR . Chemical constituents and antioxidant activity of Alstonia boonei. Afr J Biotechnol. 2007; 6(10):1197-201.

56. Okwu DE and Emenike IN. Evaluation of phytoconstituents and vitamins content of citrus fruits. International Journal of Molecular Medicine and Advance Sciences. 2006;2(1):1-6.

57. Biswal S. Oxidative stress and astaxanthin: The novel super nutrient carotenoid. International Journal of Health and Allied Sciences. 2014;3(3):147-53. 


\section{GRAPHICAL ABSTRACT}

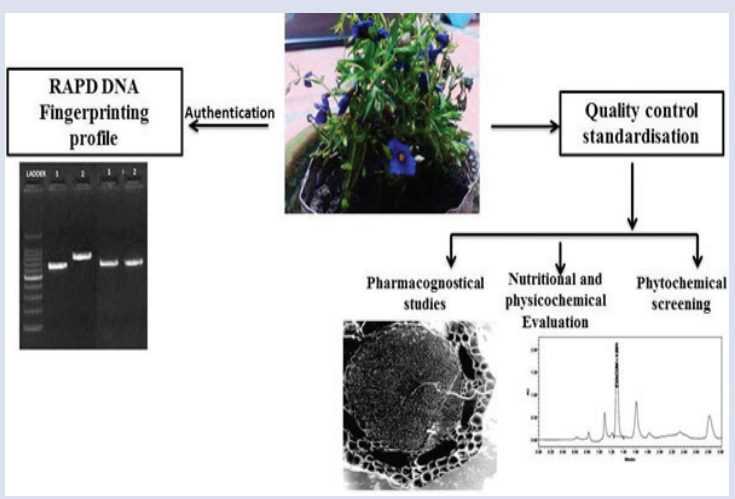

\section{SUMMARY}

- Exacum lawii (Gentianaceae) is bitter folk medicinal herb.

- Random amplified polymorphic DNA (RAPD) fingerprinting profile was performed.

- Quality control standardization including nutritional analysis, physicochemical analysis and phytochemical screening.

- HPLC standardization of Exacum lawii extract using Swertiamerin and Ursolic acid as standard.

- Some phytoconstituents were identified by GCMS analysis.

\section{ABOUT AUTHORS}

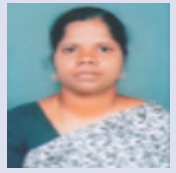

Dr. S. Hemalatha: Is working as Associate Professor in Pharmacognosy, Department of Pharmaceutical Engineering \& Technology, Indian Institute of Technology (Banaras Hindu University), Varanasi .She has an experience of more than 19 years in the field of academics and research and published more than 100 research and review articles in International and National peer reviewed journals and has also co-authored two books and one book chapter. She has supervised Ph.D and M.Pharm students and also successfully completed two projects sanctioned by the National Medicinal Plant Board (NMPB) and AICTE related to standardization of medicinal plants. She served as potential reviewer of various National and International journals.

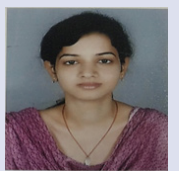

Sonam Sharma: Research scholar in Department of Pharmaceutics, Indian Institute of Technology, Banaras Hindu University. She is pursuing her PhD in Pharmacognosy. Her doctoral research is focused on Pharmacognostical and Ethnopharmacological evaluation of medicinal plants.

Cite this article: Sharma S, Hemalatha S. DNA Fingerprinting Profile and Quality Control Standardization of Folklore Medicinal Plant Exacum lawii. Pharmacog J. 2017;9(6):775-85. 